\title{
Security Equipment and Policing in Central Senatorial District of Cross River State, Nigeria
}

\author{
Ukwayi, J. K. Okpa, J. T. Adewoyin, S. A. Angioha, P. U. Udom, H. T. \\ Assistant Lecturer, Department of Sociology, University of Calabar, Nigeria. \\ Associate Professor, Department of Sociology, University of Calabar, Nigeria. \\ Graduate Student, Department of Sociology, University of Calabar, Nigeria. \\ Graduate Student, Department of Sociology, University of Calabar, Nigeria. \\ Graduate Student, Department of Social Work, University of Nigeria, Nsukka.
}

\begin{abstract}
The study investigated the effect of security equipment on policing in Central Senatorial District of Cross River State, Nigeria. The specific objectives of the study includes: to determine how functional patrol vehicles, the availability of walkie-talkie affects policing, and whether arms and ammunition are adequate and effectively used in policing. Three null hypotheses were formulated based on the identified sub-independent variables namely: patrol vehicles, walkie-talkie, arms and ammunition and the independent variable policing. Survey design was adopted in this study. A 27-item questionnaire captioned "Questionnaire on security equipment and policing" (QSEP) was developed by the researcher and used in gathering data for the study. Data was elicited from 320 police officers who were purposively selected from five (5) Divisional Police Headquarters in Central Senatorial District of Cross River State. The generated data were statistically tested using Pearson Correlation Coefficient statistical technique. Findings revealed a significant relationship between patrol vehicles, walkie-talkie, arms and ammunition, and policing. The study concluded that the effect of security equipment on policing in Cross River State is significant. The study recommended among others that government should appraise or periodically review existing security equipment in the force with the aim of reequipping the force. The police authority should appraise previous reports, research findings and information on state of police equipment with the aim of adequately equipping the police force.
\end{abstract}

Keywords: Security equipment, patrol vehicles, walkie-talkie, arms and ammunition, policing

\section{INTRODUCTION}

It is an obvious fact that equipment plays an indispensable, necessary and essential role in any human organization (Okpa, 2015). Equipment has been widely viewed as one of the most significant assets any organization can boost of, as organizations partly rely on them in performing their duties. Essentially, the availability of working tools in any institution promotes professionalism and efficiency. This practice is also applicable to security agencies that depend on this equipment for the discharge of their statutory responsibility. Security equipment such as patrol vehicles, communication gadgets, arms and ammunition, baton, pepper spray, helmet has been used all over the world by various security outfits to combat insecurity(Okpa, 2015). The police have frequently depended on these equipment to enhance its effectiveness in fighting crime and preventing break down of law and order. This equipment has enabled the police to carry out routine patrol, criminal investigation, intelligence gathering, surveillance, as well as enhance greater service delivery to the public (Sote, 2013).Observations showed that despite the huge benefits of security equipment to the police force, in Nigeria, it has received inadequate attention from government and the private sector. Records revealed that commonly used security equipment such as patrol vehicles, communication gadgets, arms and ammunition, baton, pepper spray, helmet, etc are grossly inadequate and the existing ones are in general state of disrepair (Okpa, 2015). In addition, most police formations and stations lack working tools such as stationeries', working space, and other convenience (Omidieyi, 2012). These have negatively impacted on the performance and morale of officers and men of the force in general.According to Alemika and Chukwuma (2004), the apparent inability of the prosecutorial agent of the state to combat the crime phenomenon is usually blamed on institutional constraint. Top among them is lack of sophisticated crime control equipment. Others include inadequate manpower (knowledge, power and skills), poor welfare package, as well as lack of assistance/information from civil society. Alemika and Chukwuma (2006) observed that the qualitative and quantitative inadequacies of men and women, materials (security equipment), as well as poor and inadequate social infrastructures within the Nigerian 
society, militate against police effectiveness. They posit that an ineffective police force cannot guarantee the security of citizens. While those factors militating against the Nigeria police force abound in most scholarly literature, however, there is near absence of empirical facts on how security equipment affect policing in Nigeria. This research is set to bridge this knowledge gap by critically examining some security equipment used by the Nigeria police force, and how it affects the operational efficiency of the force. Specifically, the study was designed to investigate the effect of security equipment such as patrol vehicles, communication gadgets, arms and ammunition on policing in Central Senatorial District of Cross River State, Nigeria. In other to achieve the purpose of this study, the following research questions were formulated to guide the study:

(i) Is there any relationship between functional patrol vehicles and policing in Central Senatorial District of Cross River State?

(ii) Does availability of walkie-talkie assist in policing in Central Senatorial District of Cross River State?

(iii) What is the effect of adequate arms and ammunition on policing in Central Senatorial District of Cross River State?

\section{$1.1 \quad$ Objectives of the study}

The general objective of this study is to investigate whether a relationship exists between security equipment and policing in Central Senatorial District of Cross River State, Nigeria. Specifically, the study sought to:

(i) Determine the effect of functional patrol vehicles (as a part of security equipment) on policing in Central Senatorial District of Cross River State.

(ii) Examine whether the availability of walkie-talkie (as part of security equipment) promotes policing in Central Senatorial District of Cross River State.

(iii) Investigate whether arms and ammunition (as part of security equipment) are adequate and effectively used in policing in Central Senatorial District of Cross River State.

\subsection{Research hypotheses}

Based on the objectives and research questions of this study, the following hypotheses were stated and tested:

(i) Functional Patrol vehicles are not significantly related to policing in Central Senatorial District of Cross River State.

(ii) There is no significant relationship between availability of walkie-talkie and policing in Central Senatorial District of Cross River State.

(iii) Adequate arms and ammunition does not significantly relate to policing in Central Senatorial District of Cross River State.

\section{$1.3 \quad$ Study area}

This study was carried out in Central Senatorial District of Cross River State, Nigeria. The Central Senatorial District of Cross River State stretches between longitude 7.00 to $858^{\mathrm{E}}$ and Latitude 5.000 to $5.29^{\mathrm{N}}$. The area is located midway between Cross River South and the Northern Senatorial District. It is bounded in the north by Ogoja, Obudu, and Obanliku Local Government areas of Northern Senatorial District of Cross River State, and in the south by Biase and Akamkpa Local Government areas, in the east by Republic of Cameroon, and Ebonyi State in the West. For administrative convenience, the Central Senatorial District of Cross River State is divided into six local government areas, namely: Abi, Yakurr, Ikom, Etung, Boki, and Obubra. It has a projected population of 775,250 and is occupying an area of 2005 square Kilometres (Williams, Akpama, Ayang \& Iferi-Obeten, 2013). The people of Central Senatorial District like any other district is believed to have migrated from the Bantu race of Central Africa. The influence of the early missionaries is significantly felt in this area. Thus, Christianity is the predominant religion. Generally, the people cherish their culture and tradition. Like all patriarchal society, the area enjoys a rich cultural heritage, elaborately manifested in their traditional dances, marriages, customs, chieftaincy, age grades, and festivals. These festivals include Leboku New Yam Festival in Yakkur, Aji cultural festival, among others. The presence of huge economic and tourism potentials in the area coupled with other socio-political and ethno-cultural activities of the district, makes policing inevitable. To this end, the challenges of providing secured operational environment for all these activities brought about the establishment of police formations across the length and breadth of the district. For instance, the Divisional Police Headquarters in Abi Local Government Area became a divisional police headquarters when the local government was created in 1989. The station is located in Itigidi, the headquarters of Abi Local Government. The Divisional Police Headquarters in Yakurr, was also established immediately after the creation of Yakurr

DOI: 10.9790/0837-2202050614 www.iosrjournals.org $7 \mid$ Page


Local Government Area in 1989. The station is located in Ugep, the Headquarters of Yakurr Local Government Area. Similarly, the Divisional Headquarters in Etung was established in 1996 and the station is cited in Mfum, Etung Local Government Area. Also, the Police Division at Ikom was established in the 1950s and is located in Ikom Local Government Area. While the Police station at Obubra was established in 1950s, the station is cited in Obubra.

\section{LITERATURE REVIEW AND THEORETICAL FRAMEWORK}

\section{$1.4 \quad$ Information communication technology and policing}

Information Communication Technology has been applied globally in crime prevention and control. For better and timely service delivery, the police globally make use of Information Communication and Technology (ICT) in the discharge of their statutory mandate. According to Kurmar (2012) and Regina (2013), the task of providing security, gathering intelligence as well as carrying out investigation is thoughtful activity, these activities they maintain needs the integration of numerous sources of information within a limited time. The police duties have been revolutionised through the use of information communication technology equipment. Quarshie (2014) posits that this equipment has aided the operations of the police in different parts of the world to monitor road traffic, carry out investigations with ease and track criminal elements within the shortest possible time. The police in Western Australia through the use of information communication technology equipment have reduced crime drastically through the use of predictive analytics and GPs maps which show crime hot areas in the region. Also, through the use of Business Intelligence (BI), the police have been able to build up a picture of crimes committed over the past five years in the region (Radcliffe, 2009). The United States of America police department utilizes GPs technology equipment as part of their crime prevention and control mechanism. The GPs-based law enforcement technology has been used by American police department to respond to emergency, patrol management, individual and vehicle tracking and gunshot detection (Norris, 2009).

Over the years the police have used the following Information Communication Technology equipment in checking the activities of criminals and law breakers.

(i) Closed Circuit Television (CCTV) Equipment: Closed Circuit Television is product of modern Technology. It is used by both corporate organisations and security agencies especially the police in monitoring and recording images of what takes place in a particular location at a particular time (Phillips, 1999; McCahill \& Norris, 2003).

According to Sethi (2013), CCTV performs the following functions:

(i) Trail the location of hoodlums

(ii) Find hostage of crime

(iii) Recognize possible observers

(iv) Spot crime perpetrators

These cameras are often installed in highways, banks, market places, motor parks, corporate offices, among others, to help monitor and record activities going on in these places (Quarshie, 2014). The cameras constantly monitor what people do. The police make use of closed circuit cameras to keep an eye on vehicular movement as well as residential areas prone to crime. CCTV technology promotes invisible policing. This implies that with the installation of CCTV camera the area is relatively secure. This technology reduces operational stress on the part of the police as they spend minimal time in patrol with greater efficiency. CCTV camera plays other important functions such as emergency response, patrol management, individual and vehicle tracking and gunshot detection (Quarshie, 2014).

(i) RFID (Radio Frequency Identification): The "RFID" is one of those modern security gadgets that aid the operations of security agencies. It provides diverse services, ranging from information about people, goods and products. The gadget makes use of radio waves to transfer data from an electronic tag or label, attached to an object, through a reader for the purpose of identifying and tracking the movement of materials across the country. The police make use of this gadget to ensure that transportation system can be verified to prevent movement of unauthorized materials, which can affect public safety.

(ii) Tracking technological equipment: The police and other security agencies have adopted the use of Global Positioning System (GPS) and Geographical information system (GIS) in fighting crime. This technology has been used by law enforcement agencies to track suspects and use their locations as evidence. 
The application of GPS in policing is not a new development as law enforcement agencies in various parts of the world have applied this technology in securing their nations.

\subsection{Transportation facilities (patrol vehicle) and policing}

Patrol vehicles are used by the police globally in carrying out their task of maintaining law and order. It aids the police in responding to crime and replying to distress calls promptly. Also, patrol vehicles are used in conveying officers to their respective bit as well as provide routine patrol within their area of jurisdiction. Metidoba, (2012) noted that some police vehicles are meant for specific duties and operations. Balogun (1999) asserts that the objective of patrol vehicle is to disperse policemen in a way that will eliminate or reduce the opportunity for misconduct by law breakers and to increase the likelihood of apprehension. He noted that patrol vehicles no doubt, have a strong deterrent effect on potential offenders. In the same vein, Fagbohun, (2007) maintains that through motorized anti patrols police officers has been able to intercept and arrest criminals without stress. Furthermore, patrol vehicles enhance quick mobilization and widespread motorized patrol.

Generally, police departments use numerous patrolling strategies: preventive patrol or directed patrol. Moreover, the duties of patrol vehicles are multifarious. They range from the pursuit and apprehension of criminals to the rendering of first-aid to the injured.

\section{$1.6 \quad$ Communication gadget (walkie-talkie) and policing}

According to Osuji (2012), communication gadgets particularly walkie-talkies are necessary instrument to fight crime and criminalities in the state. He maintained that police communication gadgets are essential assets to the safety and security initiative in any society. Advancing police communication allows law enforcement agencies to be more mobile and respond to top security issues more rapidly (Babangida, 2012). According to Osinuga (2013), effective and efficient policing can only be made possible through sound communication gadgets like walkie-talkie, repeater stations, High frequency (HF) sets, trucking equipment, Fax machines, and generating sets. Communication among law enforcement agencies is enhanced through the use of walkie-talkie. This equipment facilitates the sharing of data among police officers during operations (Egobiambu, 2014). It also helps the police in reducing the chances of criminals escaping; thus increasing the chances of the police officers to apprehend criminals through shared information.

\subsection{Weapons (arms and ammunition) and policing}

Police officers need to legitimately carry arms to incapacitate dangerous armed criminals and are constitutionally empowered to make use of arms during their daily tasks. In the discharge of duties placed on the police by the constitution, the police occupy a strategic position. However, their visibility, contact with the public and their use of arms has kept them in the forefront of public thought, particularly since the end of the Nigerian Civil War in 1970, when the incidence of violent crimes witnessed an accelerated increase. The Nigerian Police Force (NPF) has to resort to an increased use of firearms in its daily task of law enforcement because of the nature of arms used by hoodlums and criminals. Makinde (2014) avers that for proficient handling of armed bandits the police force needs to be adequately reinforced with sophisticated weapons such as arms and ammunition, teargas, hand/blast grenade, long/short range teargas, bulletproof vest, cartridges, etc. The Nigeria Police Force has inadequate arms, logistics, telecommunication gadgets, and transportation facilities. The police needs to be empowered with sophisticated weapons to it enable confront criminals or armed robbers who are usually armed with sophisticated weapons. However, the police should be restricted to the use of these arms as a last resort. Lamenting on the inadequacy of arms as a critical factor for police failure, Daudu (2008) observed that the, "Nigerian police are helpless, when confronted with armed robbers who have sophisticated rifles that the police cannot dare to withstand".

\section{$1.8 \quad$ Brief theoretical background}

\subsubsection{Technology determinism theory}

The theory is associated with Smith and Mark (1994). The theory posits that technology drives the expansion of any social system as well as its social structures. It views technology as a key governing force in the social system and contended that social progress is motivated by technological innovation. In addition, the theory asserts that technical forces determine both social and cultural change (Green, 2001). The theory has implication for this study as adequate provision of security equipment (technology) has the capacity to boost the morale and encourage police officers to effectively discharge their duties. Security equipment such as patrol vehicles, walkie-talkie, arms and ammunition, influence the operational efficiency of the police officers. Based on the assumptions of the theory, social problem such as armed robbery, kidnapping, arson, fraud, cybercrime

DOI: 10.9790/0837-2202050614 www.iosrjournals.org $9 \mid$ Page


among others can be contended through adequate supply of functional security equipment. The performance of the police officers can be enhanced or marred by the quality and quantity of security equipment they interact with. The theory has been criticised for reductionism and simplicity of social issues.

\section{METHODOLOGY}

The study opted for survey research design because the design has to do with the gathering of facts that are correctly and empirically aimed at explaining prevailing occurrences and events (Osuala, 2001). Furthermore, the design allows for the selection of samples and the generalization of findings. The population of this study consists of five Divisional Police Headquarters in Central Senatorial District of Cross River State. A breakdown of the population shows that Divisional Police Headquarters Itigidi has 116 police personnel, Divisional Police Headquarters Obubra has 92 police personnel, Divisional Police Headquarters Ugep has 205 police personnel, Divisional Police Headquarters Mfum has 75 police personnel, and Divisional Police Headquarters Ikom has 250 police personnel. The gross total of personnel in the five Divisional Police Headquarters is 738. This figure comprised rank and file, Senior Police Officers (SPOs), traffic wardens and police prosecutors. The study purposively selected a sample of three hundred and twenty (327) respondents from the five Divisional Police Headquarters in Central Senatorial District of Cross River State. A 27 items questionnaire patterned after the four likert scale Captioned "Questionnaire on security equipment and policing" (QSEP) was designed by the researcher. Data gathered from the field were coded and analysed using statistical package for social sciences (SPSS). Pearson product moment correlation (PPMC) was used to analysis the generated data.

\section{RESULTS}

The summary data for all the main variables in the study are presented in Table 1. Three hundred and twenty seven questionnaires were distributed but Three hundred and twenty were returned giving a response rate of 93 percent. Table 1 revealed respondents demographic information. The distribution of respondents shows that 28.1 per cent $(\mathrm{N}=90)$ were sampled from Ikom divisional police headquarters, 25.0 per cent $(\mathrm{N}=$ 80) were sampled from Ugep divisional police headquarters, 18.8 per cent $(\mathrm{N}=60)$ were sampled from Itigidi divisional police headquarters, 15.6 per cent $(\mathrm{N}=50)$ were sampled from Obubura divisional police headquarters while only 12.5 per cent $(\mathrm{N}=40)$ were sampled from Etung divisional police headquarters, the variance in the sample distribution is not within the control of the researcher since the number of police officers varies across divisions. The spread of respondents in respect to gender shows that 91.6 per cent $(\mathrm{N}=293)$ are male while only 8.4 per cent $(\mathrm{N}=27)$ are female. The high number of male respondents over the female respondents is a sign that during recruitment more male are recruited than female into the force. The rational for this might be associated with the tough bodily features of male as the task of policing needs physical ability and dexterity. Respondents responses to marital status reveals that majority 70.6 per cent $(\mathrm{N}=226)$ are currently married, 21.3 per cent $(\mathrm{N}=68)$ are single while only 8.1 per cent $(\mathrm{N}=26)$ are divorced, separated or widowed. This was not out of place because most of the respondents were of marriageable age, therefore the high percentage of the married among the population of study. Approximately 21.3 percent were single, 8.1 percent have either divorced their spouse, separated or hand lost their partners to deaths.The spread of respondents in terms of age shows that majority 30.6 per cent $(\mathrm{N}=98)$ are between the ages of $46-55$ years, 26.9 per cent $(\mathrm{N}=$ 86) are between the ages of 36-45 years, 19.1 per cent $(\mathrm{N}=61)$ are between the ages of 26-35 years, 14.4 per cent $(\mathrm{N}=46)$ are between the ages of 56 years and above while only 9.1 per cent $(\mathrm{N}=29)$ are below 25 years, all the age group are represented since police operations do not exempt any officer but involves all the officers on duty this is not controlled by the researcher. The compartmentalization of respondents in term of highest educational level revealed that majority of the respondents 47.5 per cent $(\mathrm{N}=152)$ have completed secondary school education, 41.3 per cent of the respondents $(\mathrm{N}=132)$ have completed primary education, the least group are respondents with higher educational certificate with a representation of 11.3 per cent $(\mathrm{N}=36)$ This indicates that the respondents are literates. The great level of educational achievement among the population of study may possibly be credited to extraordinary importance given to education achievement by the police authority.

Majority of the respondents in respect to religious affiliation 90.0 per cent $(\mathrm{N}=288)$ practice Christianity; Islam faithful have a representation of 5.6 per cent $(\mathrm{N}=18)$; the group with the least representation are African Tradition Religion Faithfull's with 4.4 per cent $(\mathrm{N}=14)$ More of the respondents are Christians because the study is carried out in Christian dominated area. The working experience of officers sampled broadly group into three categories; majority the respondents 45.9 per cent $(\mathrm{N}=147)$ have experience on the job for about $10-20$ years, 37.2 per cent $(\mathrm{N}=119)$ have experience on the job for about 21 years plus, while only 16.9 per cent $(\mathrm{N}=54)$ have below 10 years experience on the job.The compartmentalization of the residential 
status of the respondents show that majority of the respondents 64.4 per cent $(\mathrm{N}=206)$ reside off barrack; while barrack residents in the sample were 35.6 per cent $(\mathrm{N}=114)$, this spread is conditioned by the number of bed spaces in the barrack and the large families of police officers. In addition, the high proportion of officers residing off barracks could be attributed to the non-availability of barrack accommodation in Itigidi and Etung divisional police headquarters. Also, the dilapidated nature of barracks accommodation made some of the respondents to rent accommodation outside. The implication of a lot of police officers residing off barracks is that of organising the men and women during distress call is always problematic.

TABLE 1PERSONAL/DEMOGRAPHIC INFORMATION OF RESPONDENTS

\begin{tabular}{|c|c|c|c|}
\hline VARIABLE & & $\mathrm{N}$ & Percentage \\
\hline \multirow[t]{6}{*}{ Location of respondents } & Ikom DHQ & 90 & 28.1 \\
\hline & Etung DHQ & 40 & 12.5 \\
\hline & Ugep DHQ & 80 & 25.0 \\
\hline & Itigidi DHQ & 60 & 18.8 \\
\hline & Obubura DHQ & 50 & 15.6 \\
\hline & Total & 320 & 100 \\
\hline \multirow[t]{3}{*}{ Gender } & Male & 293 & 293 \\
\hline & Female & 27 & 27 \\
\hline & Total & 320 & 100 \\
\hline \multirow[t]{4}{*}{ Marital status } & Single & 68 & 21.3 \\
\hline & Currently married & 226 & 70.6 \\
\hline & Divorced/separated/widowed & 26 & 8.1 \\
\hline & Total & 320 & 100 \\
\hline \multirow[t]{6}{*}{ Age of respondents } & Below 25 years & 29 & 9.1 \\
\hline & $26-35$ years & 61 & 19.1 \\
\hline & $36-45$ years & 86 & 26.9 \\
\hline & $46-55$ years & 98 & 30.6 \\
\hline & 56 years and above & 46 & 14.4 \\
\hline & Total & 320 & 100 \\
\hline \multirow[t]{4}{*}{ Highest Educational Qualification } & Completed Primary & 132 & 41.3 \\
\hline & Completed secondary & 152 & 47.5 \\
\hline & Completed Tertiary & 36 & 11.3 \\
\hline & Total & 320 & 100 \\
\hline \multirow[t]{4}{*}{ Religious affiliation } & Christianity & 288 & 90.0 \\
\hline & Islam & 18 & 5.6 \\
\hline & ATR & 14 & 4.4 \\
\hline & Total & 320 & 100 \\
\hline \multirow[t]{4}{*}{ Working experience } & Below 10 years & 54 & 16.9 \\
\hline & $10-20$ years & 147 & 45.9 \\
\hline & 21 years and above & 119 & 37.2 \\
\hline & Total & 320 & 100 \\
\hline \multirow[t]{3}{*}{ Residence } & Barrack & 114 & 35.6 \\
\hline & Off barrack & 206 & 64.4 \\
\hline & Total & 320 & 100 \\
\hline
\end{tabular}

\section{Hypothesis I}

Hypothesis one states that, patrol vehicles are not significantly related to policing in Central Senatorial District of Cross River State. To test the hypothesis, Pearson product moment correlation analysis was used to analyse the data. As presented in Table 2, the calculated $r$-value of $0.338 * *$ is greater than the critical $r$-value of 0.138 with 318 degree of freedom, this result therefore implies that the null hypothesis which states that, patrol vehicles are not significantly related to policing is rejected. It therefore means that, there is statistical significant relationship between the availability of patrol vehicle and policing.

TABLE 2Pearson product moment correlation of patrol vehicle and policing

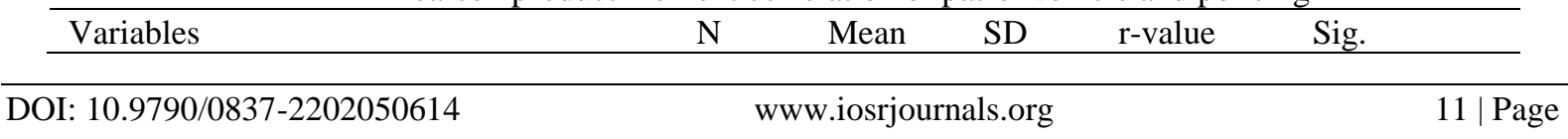




\begin{tabular}{|c|c|c|c|c|c|}
\hline Patrol vehicle & 320 & 16.34 & 1.89 & $0.338 * *$ & .000 \\
\hline Policing & 320 & 16.61 & 1.35 & & \\
\hline
\end{tabular}

\section{Hypothesis II}

Hypothesis two states that, there is no significant relationship between walkie-talkie and policing Central Senatorial District of Cross River State. Pearson product moment correlation analysis was used to analyse the data. As presented in Table 3, page 73 the calculated r-value of $0.392 * *$ is greater than the critical $r$ value of 0.138 with 318 degree of freedom. This result therefore implies that the null hypothesis which states that, there is no significant relationship between walkie-talkie and policing is rejected. It therefore means that, communication gadgets (walkie-talkie) significantly aid policing.

TABLE 3Pearson product moment correlation of walkie-talkie and policing

\begin{tabular}{llllll}
\hline Variables & $\mathrm{N}$ & Mean & SD & r-value & Sig. \\
\hline Walkie-talkie & 320 & 14.52 & 1.47 & & \\
& & & & $0.392 * *$ & .000 \\
Policing & 320 & 16.61 & 1.35 & & \\
\hline
\end{tabular}

*significant at $\mathrm{P}<.05 ;$ critical $\mathrm{r}$-value $=0.138 ; \mathrm{df}=318$.

\section{Hypothesis III}

Hypothesis three states that, arms and ammunition is not related to policing in Central Senatorial District of Cross River State. Pearson Product Moment Correlation Analysis was employed to analyse the data. As presented in Table 4.9, page 74 the calculated r-value of $0.440 * *$ is greater than the critical r-value of 0.138 with 318 degree of freedom, this result therefore implies that the null hypothesis which states that, arms and ammunition is not related to policing. It therefore means that, there is statistical significant relationship between the availability of arms and ammunition and effective policing.

TABLE 4Pearson product moment correlation of arms and ammunition and policing

\begin{tabular}{llllll}
\hline Variables & $\mathrm{N}$ & Mean & SD & r-value & Sig. \\
\hline Arm and ammunitions & 320 & 14.90 & 1.87 & & \\
& & & & $0.440^{* *}$ & .000 \\
Policing & 320 & 16.61 & 1.35 & & \\
\hline
\end{tabular}

*significant at $\mathrm{P}<.05 ;$ critical r-value $=0.138 ; \mathrm{df}=318$.

\section{$1.9 \quad$ Discussion of finding}

\subsubsection{Patrol vehicles and policing}

Scholarly contributions on the relationship between patrol vehicles and policing cannot be overlooked when discussing the above subject. Scholars such as Balogun (1999), Fagbohun (2007), Metidoba (2012) contend that an increase in the number of patrol vehicles, provision of fuel, as well as frequent maintenance of patrol vehicles could generally lead to proficient policing in Nigerian and Cross River State in particular. These scholars avers that provision of functional patrol vehicles will assist the police during routine patrol as well as respond to emergencies and distress calls. This findings support the position of the scholars. Balogun (1999) reported that an association exists between patrol vehicles and policing. He asserts that patrol vehicles helps in dispersing police personnel in such a way that lessen the chance for misdemeanours by law breakers. In addition it raises the prospect of apprehension of criminals. He observed that the more patrol vehicles are made available and accessible by the police, the more enhanced their performance during operations. He maintained that Nigeria police force can only be effective and efficient in the discharge of duties when enough patrol vehicles is made available to them by the government, private companies, as well as multi-national companies.

\subsubsection{Walkie-talkie and policing}

The result of the statistical analysis of hypothesis two shows that there is a significant relationship between walkie-talkie and policing. From the analysis, the value was positive which indicated that the availability of more walkie-talkie would enhance communication during operations, thereby increasing the 
effectiveness and efficacy of the police force during operations. The findings agree with Fgbobiambu (2014) who posit that, police operational efficacy is associated with the use of walkie-talkie among members of the force and their base. This equipment facilitates the sharing of data among police officers during operations.

Osuji (2012) observations was supported by this study. According to him, walkie-talkie is an essential device used by the police to combat criminal activities in the world at large. The finding is consistent with the observation of Osinuga (2014) who posits that effective and efficient policing can only be made possible through information sharing and communication during operation. The explanation of this relationship is that exchange of information and communication during operations is made possible through the use of walkie-talkie facilities.

\subsubsection{Arms and Ammunitions, and policing}

The result of the statistical analysis of hypothesis three of this study revealed that arms and ammunitions is significantly related to efficient policing. The valve was positive which implies that increase supply of arms and ammunitions would strengthen the performance of police officers.

The findings agree with Dauda (2008) who states that police officers need sophisticated arms and ammunitions to incapacitate dangerous armed criminals. These findings are in support of Makinde (2014) who avers that for the proficient handling of armed bandits, the police force needs to be adequately reinforced with sophisticated weapons such as arms and ammunition, teargas, hand blast grenade, bulletproof vest among others. Ajayi (2011) findings have been supported by this study. He observed that the police needs to be empowered with arms superior to the ones used by criminals, so that when confronted with hoodlums they will be able to withstand and overpower them.

\section{CONCLUSION AND RECOMMENDATIONS}

The thrust of this study was to investigate the effect of security equipment on policing in Central Senatorial District of Cross River State, Nigeria. Specifically, the study examined the correlate between patrol vehicle, walkie-talkie, arms and ammunition, and policing. It was therefore concluded that security equipment affects policing in Central Senatorial District of Cross River State in particular and Nigeria in general. Based on these findings, the following recommendations were made:

(i) The police authority should appraise previous reports, research findings and information on state of police equipment with the aim of adequately equipping the police force.

(ii) Government should periodically review police equipment to ensure that the force is up to date with sophisticated patrol vehicles, walkie-talkie, arms and ammunition among others.

(iii) Adequate patrol vehicles, walkie-talkie, and arms and ammunition should be provided to different police commands and divisions to enhance their operational efficiency.

(iv) The police authority should ensure that police recruits are well-educated to handle all equipments at their disposal. More importantly, training and retraining of police personnel should be undertaken periodically to keep officers abreast of technological innovations on police equipments.

\section{REFERENCES}

[1] Ajayi, F. (2013). Crime control in Nigeria: the odds against the police. The International Journal Research of Social Sciences and Management, 3(5), 15-19

[2] Alemika, E. E. O. \& Chukwuma, I. C. (2004). Crime and policing in Nigeria: challenges and options network on police reform in Nigeria Lagos: Cleen Foundation.

[3] Alemika, E. E. O. \& Chukwuma, I. C. (2006).Criminal victimization, safety and policing in Nigeria. Monograph series, No 6. Cleen Foundation Lagos.

[4] Babangida, M. (2012). The search for National Security in Nigeria: challenges and prospects. A paper presented at a public lecture at Obafemi Awofowo Institute of Government Mushin-Lagos.

[5] Balogun, T. (1999). Police welfarism and state police agitation: $2^{\text {nd }}$ national workshop on security of life and property in Nigeria. The Dawn, 3(5), 7-9.

[6] Daudu, M. (2008).Commenting on the helpless state of police when confronted with armed robbers. Tell magazine 6 (4), 14.

[7] Egobiambu, E. (2014). Place of technology in crime fighting. The Nigerian Observer, 4(18), 5.

[8] Fagbohun, O. O. (2007). Improving the policing system using electronic policing, Journal of Engineering and Applied Science 2(7), 67-74.

[9] Green, L. (2001). Techno-culture. Crows Nest: India. Allen and Unwin. 
[10] Kurmar, B. (2012). Role of information communication technology in Indian police, GianJyotic-Journal, $1(2), 10-13$.

[11] Makinde, A. (2014). Remedying the maladies of the Nigeria Police Force. Daily Independent Newspaper, $3(7), 68$.

[12] McCahill, M. \& Norris, C. (2003). CCTV and public attitudes report to the European Commission fifth frame-work RTD as part of the Urban Panopticon Project.

[13] Metidoba, S. (2012).Modern crime prevention and control strategies, implications for developing countries. Ph.D Dissertation, Department of Sociology, University of Ilorin, ILORIN, Nigeria.

[14] Okpa, J.T. (2015). Security equipment and policing in central senatorial district of Cross River State, Nigeria. An M.Sc. Thesis submitted to the Department of Sociology, University of Calabar, Calabar.

[15] Omidieyi, O. (2012). Police reform and restore Turing in Nigeria. Part 3. The Dawn, 4 (021), 9-10.

[16] Osinuga, O. O. (2013). An agenda for effective policing in Nigeria, an international criminal lawyer works in the mission of leading international governmental organization in Europe. Abuja. Dell publishers

[17] Osuala, E. C. (2001). Introduction to research methodology $3^{\text {rd }}$ ed. Onitsha: Africana-Fep Publishers.

[18] Osuji, C. (2012). Nigeria police: most misunderstood, underrated and vilified-why? The Dawn, 4 (003), 5.

[19] Phillips, C. (1999). A review of CCTV evaluations: crime reduction effects and attitude towards its use. In k. Painter \& N. Tilley (eds), Surveillance of public space: CCTV, street lighting and crime prevention, crime prevention studies. New York. Criminal Justice Press.

[20] Quarshie, H. O. (2014). Using ICT to fight crime a case of Africa. Journal Of Engorging Trends In Computing And Information Science, 1(1), 21-24.

[21] Radcliffe, J. (2009). Video surveillance of public place. New York: Centre for Problem Oriented Policing.

[22] Regina, O. N. (2013). The impact of information and communication technology (ICT) on teacher education and its implication for professional development in Nigeria. International journal of learning \& development 2(3) 35-47

[23] Sethi, V. (2013). Role of ICT in police force India, International Journal of Advanced Research in Computer Science and Software Engineering, 3(71), 778-781.

[24] Sote, L. (2013). Helping the police to help Nigeria. The Punch Newspaper, 10 (29), 15.

[25] Williams, B. S., Akpama, E. G., Etelbert, E., Iferi-Obenten, M. (2013). The implications of the application of best assessment practices on the basic education teachers' characteristics: A case study of the cross River central senatorial district. Africa Journal of Education and Technology. 3(1), 37-39. 